\title{
Development of Science Learning Tools on Vibration, Waves, and Sound Topics
}

Fajar Kurnia*, Suryajaya, Yudha Irhasyuarna

Master of Teacher Training In Natural Science Education, Lambung Mangkurat University

\begin{tabular}{ll}
\hline DOI: $\underline{10.36348 / \text { jaep.2020.v04i08.002 }}$ & | Received: $19.08 .2020 \mid$ Accepted: $26.08 .2020 \mid$ Published: 30.08 .2020 \\
*Corresponding author: Fajar Kurnia &
\end{tabular}

\section{Abstract}

This study aims to determine the feasibility of a guided inquiry model of physics science learning device on the topic of vibrations, waves and sound. The development of the tools was carried out based on the Tessmer development research model so as to produce a proto-type that was tested up to the field test stage. The data analysis technique is descriptive quantitative. The appropriateness of the learning device is stated from its validity, practicality, and effectiveness. The validity of learning devices can be determined from the results of validation by experts and the results of individual trials. Practicality is determined from the implementation of the lesson plan and the responses of teachers and students to learning devices. Effectiveness is determined by the ability of students in implementing worksheets, cognitive learning outcomes, teacher and student activities, social skills, character behavior, and students' psychomotor skills. The results of development research show that the learning tools are valid, practical, and effective. Based on the results of descriptive analysis, it can be concluded that the learning tools that have been developed can apply the Guided Inquiry learning model well.

Keywords: Device development, science learning, guided inquiry.

Copyright @ 2020: This is an open-access article distributed under the terms of the Creative Commons Attribution license which permits unrestricted use, distribution, and reproduction in any medium for non-commercial use (NonCommercial, or CC-BY-NC) provided the original author and sources are credited.

\section{INTRODUCTION}

Based on Permendikbud RI No. 65 of 2013 states that the learning objectives in the Graduate Competency Standards (SKL) include the development of the realms of attitudes, knowledge and skills. These three realms have different psychological processes. Attitudes are obtained through the activities of receiving, running, appreciating, living, and practicing, while knowledge is obtained through activities of remembering, understanding, applying, analyzing, evaluating, and creating and skills acquired through observing, questioning, trying, reasoning, presenting, and creating. Increasing the achievement of graduate competencies symbolizes the progress and development of the quality of education of a nation, this is important in responding to the demands of the times and demands of technology and responding to the challenges of globalization [1].

The current development of the quality of education in Indonesia has not shown satisfactory results. The quality of Indonesian education is still low according to the results of the Trends in International Mathematics and Science Study (TIMSS) survey because it is below the international average score. This is based on a report issued by TIMSS on the results of the 2007 test which showed that the achievement of Indonesian students in the education sector was in a low ranking position. In the field of Mathematics and Natural Sciences, the achievement of Indonesian students is in 36th place out of 49 countries surveyed [2]. The 2015 PISA results report shows that the science score of Indonesian students is 403, and Indonesia is ranked 64th out of 72 OECD participating countries, or in other words, it is ranked the lowest ninth of all PISA participating countries [3]. The era of globalization demands high competitiveness, this of course must be equipped with skills. The role of education is very necessary in preparing skills, especially for students so that later they are able and ready to compete in their present and future lives.

Efforts to improve the quality of science education in Indonesia need to be based on scientific studies, thus enabling these efforts to produce effective solutions [4]. One of the efforts that can be made to increase the achievement of values in SKL is through a learning model that is right on the concepts that will be taught by the teacher by involving students in teaching and learning activities so that they are able to explore to 
Fajar Kurnia et al., J Adv Educ Philos, August, 2020; 4(8): 351-360

form competencies by exploring various potentials, scientific truth and explore students' thinking skills. Therefore, the government has made a policy stated in Permendikbud number 65 of 2013 disclosure/researchbased learning. This is a challenge for teachers to apply learning that can attract students' attention by observing directly in obtaining lesson information, namely using a scientific approach and training student skills.

Learning activities are expected to be contextual, not only covering the cognitive realm but also psychomotor and affective and in accordance with the conditions of the student's learning environment. According to Amri, et al. [5], the contextual learning approach process is a learning method that helps all teachers practice and associate the material taught with the situation in the student environment and requires students to make connections with some of the knowledge students have experienced with its application in their lives as members. family and community. The guided inquiry learning model is not something new in classroom learning, but this model is still relevant for exploring students' thinking abilities.

According to Ambarasari [6] the learning model used in teaching and learning activities also affects student achievement. The learning model must be in accordance with the material being taught by the teacher. Innovative learning models will also arouse student interest in participating in the learning process, because students will not be bored with participating in teaching and learning activities so that student learning achievement will be better.

The learning process of the guided inquiry model is based on constructivism theory, where students actively build their own knowledge. The teacher acts as a motivator, facilitator and guide. Inquiry is a learning model that stimulates, teaches and invites students to think analytically and systematically in order to find answers independently of the various problems raised [7]. McBride, et al., [8] added that science teaching through inquiry involves the process of science and skills used by scientists to learn about the world and helps students apply these skills involved in learning science concepts. Students are helped to learn and apply the process by carrying out problem-based investigations designed to learn scientific concepts. Teachers help students generate questions to guide investigations.

Schaal, et al., [9] reported that the results of inquiry-based learning showed evidence of successful learning about biodiversity in the field. Thus, it can be a way of providing experience for teachers in the field. Kong, et al., [10] reported the findings of interviews and pre-test and post-test studies showing that learning in a resource-based environment can help learners to build knowledge about family trees. The teacher's role in such an environment is to guide and encourage students to ask questions during the learning process. This requires an inquiry process in which learners are involved in searching, understanding, organizing, synthesizing and evaluating information from various sources of information. Meidawati [11] reports that the guided inquiry model approach affects students' mathematical problem solving abilities.

The Guided Inquiry Learning Model in science learning is less applied at SMPN 33 Banjarmasin, especially the concept of vibrations, waves and sound. Based on the value obtained from all the results of daily tests, the lowest daily test scores on Vibration, Waves and Sounds obtained the following data: the average score of children was 61.7 with the highest score 95 and very low score. This value is lower than the other chapter materials. The National Exam Result Report of 12 materials used as material, the absorption of vibration, wave and sound topics in the National Exam from 2012 to 2014 shows a significant downward trend [12]. Then, according to research conducted by Nasir, et al. [13]. The guided inquiry learning model makes students more active and independent. Students are given the freedom to design their own investigations.

\section{RESEARCH METHODS}

This study uses the Tessmer development model [14] with five steps from self-evaluation, expert opinion, individual test, small group test, and field test. The prototype is tested repeatedly through these five steps by looking at the validity, practicality, and effectiveness so that the final product can pass the test. The trial design of this product is guided by the formative evaluation flow. Validity is obtained from expert opinion and suggestions (expert review) guided by validation instruments which include content validation. The practicality of the product is obtained through small group testing of partner teachers. Effectiveness is obtained through small group trials and field trials. The total sample is 45 students in $8^{\text {th }}$ grades. For the validity test, there are two lecturers who are experts in the field of science education or related subjects and one teacher as a practitioner in the world of education.

Data collection was carried out by observation, documentation, and tests. Instruments for determining the level of practicality include instruments for observing the implementation of learning, response questionnaires, and self-regulation. Instruments for determining the level of effectiveness include cognitive test sheets, psychomotor observation sheets, affective observation sheets, and student worksheets (LKS). The data analysis technique used in this research is quantitative descriptive analysis.

\section{RESEARCH RESULTS AND DISCUSSION Research Results}

The development of learning tools goes through various processes to become a prototype in the 
Fajar Kurnia et al., J Adv Educ Philos, August, 2020; 4(8): 351-360

form of a complete device that is ready for further demination with the aim of improving the quality of science learning in physics in schools. The stages taken are initial evaluation and finalization, validation and individual trials, small group trials and field trials. The advanced stage in field trials is a semi-summative test conducted in different classes to see the comparison or effectiveness of the learning tools to be developed.

\section{Expert Validation and Practitioner}

Table-1: The results of the tool validity recap by Experts and Practitioners

\begin{tabular}{|c|c|c|c|c|c|c|c|}
\hline \multirow{2}{*}{ No. } & \multirow[t]{2}{*}{ Component } & \multicolumn{3}{|c|}{ Phase I } & \multicolumn{3}{|c|}{$\begin{array}{r}\text { Phase II } \\
\end{array}$} \\
\hline & & Final Score & $\%$ & Desc. & Final Score & $\%$ & Desc. \\
\hline 1 & Syllabus & 27.7 & $69 \%$ & $\mathrm{CV}$ & 35.0 & $88 \%$ & SV \\
\hline 2 & Material Analysis & 9.7 & $60 \%$ & $\mathrm{CV}$ & 12.7 & $79 \%$ & SV \\
\hline 3 & Teaching materials & 37.3 & $58 \%$ & $\mathrm{CV}$ & 54.0 & $84 \%$ & SV \\
\hline 4 & LKS & 16.7 & $42 \%$ & $\mathrm{KV}$ & 33.0 & $83 \%$ & SV \\
\hline 5 & Teacher Activity Instruments & 7.7 & $48 \%$ & KV & 13.3 & $83 \%$ & SV \\
\hline 6 & Student Activity Instruments & 10.0 & $63 \%$ & $\mathrm{CV}$ & 13.7 & $85 \%$ & SV \\
\hline 7 & Affective Instruments & 8.3 & $52 \%$ & $\mathrm{CV}$ & 12.7 & $79 \%$ & SV \\
\hline 8 & Psychomotor Instruments & 7.7 & $48 \%$ & $\mathrm{KV}$ & 13.7 & $85 \%$ & SV \\
\hline 9 & Self Regulation Instruments & 9.7 & $60 \%$ & $\mathrm{CV}$ & 13.0 & $81 \%$ & SV \\
\hline 10 & Student Response Instruments & 8.0 & $50 \%$ & KV & 12.3 & $77 \%$ & SV \\
\hline
\end{tabular}

Note: $\mathrm{SV}=$ very valid, $\mathrm{CV}=$ quite valid, $\mathrm{KV}=$ not valid, $\mathrm{TV}=$ invalid

Based on the results of the product validation test of teaching materials based on experts and practitioners in accordance with the contents of the product content of learning materials in stage I, on average, all experts and practitioners stated that they were quite valid from all validated products. Furthermore, the researchers made improvements in accordance with the suggestions given by experts and practitioners. After making improvements, the researchers re-tested the teaching material products to the experts and practitioners. The average result of testing the validity of teaching materials by experts and practitioners in stage II states that almost all of them are very valid.

\section{Practicality of Learning Tools}

The results of observations of observations of the implementation of learning are proven by observing teacher activities. The results of observations of teacher activities in the learning process are presented in Table 2 .

Table-2: Results of Observation of Teacher Activities in Learning Implementation

\begin{tabular}{|c|c|c|c|c|c|c|c|c|c|}
\hline \multirow{3}{*}{ No. } & \multirow{3}{*}{ Observed Aspects } & \multicolumn{8}{|c|}{ Observer Assessment Results } \\
\hline & & \multicolumn{2}{|c|}{ P1 } & \multicolumn{2}{|c|}{ P2 } & \multicolumn{2}{|c|}{ P3 } & \multicolumn{2}{|c|}{ P4 } \\
\hline & & Ob1 & $\mathrm{Ob} 2$ & Ob1 & $\mathrm{Ob} 2$ & Ob1 & $\mathrm{Ob} 2$ & Ob1 & $\mathrm{Ob} 2$ \\
\hline 1 & Teacher Gives greetings & 3 & 2 & 2 & 3 & 3 & 4 & 5 & 5 \\
\hline 2 & Teachers Ask Students to Pray & 2 & 2 & 3 & 3 & 3 & 3 & 4 & 3 \\
\hline 3 & The teacher motivates students by giving simple questions & 1 & 1 & 1 & 5 & 4 & 5 & 4 & 5 \\
\hline 4 & The teacher delivers the main material and learning objectives & 2 & 2 & 4 & 2 & 4 & 3 & 4 & 4 \\
\hline 5 & Teacher demonstrates Vibrations, Waves and Sounds & 3 & 3 & 5 & 4 & 5 & 5 & 5 & 5 \\
\hline 6 & The teacher directs students to formulate problems & 4 & 4 & 3 & 3 & 3 & 4 & 5 & 5 \\
\hline 7 & $\begin{array}{l}\text { The teacher arranges the students in groups of five people and } \\
\text { gives the task to do experiments on the LKPD }\end{array}$ & 3 & 3 & 5 & 3 & 5 & 3 & 5 & 3 \\
\hline 8 & $\begin{array}{l}\text { Guided by LKPD, the teacher guides students in conducting } \\
\text { experiments }\end{array}$ & 3 & 3 & 5 & 5 & 5 & 4 & 5 & 4 \\
\hline 9 & $\begin{array}{l}\text { Guided by the LKPD, the teacher instructs students to experiment } \\
\text { independently in their groups with full responsibility }\end{array}$ & 3 & 3 & 4 & 5 & 4 & 3 & 4 & 3 \\
\hline 10 & The teacher directs students to discuss groups in their experiments & 4 & 3 & 2 & 4 & 3 & 4 & 4 & 4 \\
\hline 11 & $\begin{array}{l}\text { The teacher invites the group of students to present the results of } \\
\text { the experiments that have been carried out and ask students to } \\
\text { conduct self-assessment of skills in carrying out experiments. }\end{array}$ & 3 & 3 & 4 & 4 & 4 & 4 & 4 & 4 \\
\hline 12 & $\begin{array}{l}\text { The teacher guides students to make conclusions about the } \\
\text { activities that have been carried out today }\end{array}$ & 1 & 2 & 2 & 2 & 3 & 3 & 4 & 3 \\
\hline 13 & $\begin{array}{l}\text { The teacher reinforces the concepts that students have found about } \\
\text { the subject matter that has been learned }\end{array}$ & 1 & 2 & 3 & 2 & 3 & 3 & 4 & 3 \\
\hline
\end{tabular}


Fajar Kurnia et al., J Adv Educ Philos, August, 2020; 4(8): 351-360

\begin{tabular}{|l|l|c|c|c|c|c|c|c|c|}
\hline 14 & The teacher closes the lesson by saying greetings & 5 & 5 & 4 & 4 & 4 & 4 & 5 & 4 \\
\hline Total & $\mathbf{3 8}$ & $\mathbf{3 8}$ & $\mathbf{4 7}$ & $\mathbf{4 9}$ & $\mathbf{5 3}$ & $\mathbf{5 2}$ & $\mathbf{6 2}$ & $\mathbf{5 5}$ \\
\hline Average & $\mathbf{3 8}$ & $\mathbf{4 8}$ & $\mathbf{5 2 . 5}$ & $\mathbf{5 8 . 5}$ \\
\hline Category & \multicolumn{2}{|c|}{ Bad } & $\begin{array}{l}\text { Quite } \\
\text { Good }\end{array}$ & Good & Good \\
\hline
\end{tabular}

Based on the results of observations of teacher activities at the first and second meetings it is known that the learning implementation process is going well. This is indicated by in general the process of category teacher activity activities at the first and second meetings. This shows that the teacher has carried out his role as a good speaker for his students. Based on the results of observations of teacher activities at the third and fourth meetings, it is known that the learning implementation process has increased from the previous two meetings. This is indicated by in general the process of teacher activity categories is good at the third meeting and very good at the fourth meeting. This shows that the teacher has carried out his role as a better speaker than before for students in delivering the material the learning process takes place.

Students' responses to learning activities using distributed questionnaires are presented in Table 3.

Table-3: Observation Results of Students' Responses to Meeting Learning

\begin{tabular}{|l|c|c|c|c|c|c|c|c|}
\hline \multirow{2}{*}{ Student Response } & \multicolumn{2}{|c|}{$\mathbf{1}^{\text {st }}$ Meeting } & \multicolumn{2}{|c|}{$\mathbf{2}^{\text {nd }}$ Meeting } & \multicolumn{2}{c|}{$\mathbf{3}^{\text {rd }}$ Meeting } & \multicolumn{2}{|c|}{$\mathbf{4}^{\text {th }}$ Meeting } \\
\cline { 2 - 9 } & $\mathbf{N}$ & $\mathbf{\%}$ & $\mathbf{N}$ & $\mathbf{\%}$ & $\mathbf{N}$ & $\mathbf{\%}$ & $\mathbf{N}$ & $\mathbf{\%}$ \\
\hline Good & 7 & 25 & 7 & 25 & 11 & 39 & 16 & 57 \\
\hline Quite Good & 13 & 46 & 17 & 61 & 13 & 46 & 12 & 43 \\
\hline Not Good & 8 & 29 & 4 & 14 & 4 & 14 & 0 & 0 \\
\hline Total & 28 & 100 & 28 & 100 & 28 & 100 & 28 & 100 \\
\hline
\end{tabular}

Based on student responses at the first and second meetings, it is known that students' responses to the learning process tend to increase. This is indicated by the increase in the number of students in the sufficient category and the decrease in the number of students in the poor category. This shows that student responses to changes in learning methods are very good. This is indicated by the response of students who always follow the material presented by the teacher with a delivery that is comfortable and acceptable to the students.

Based on the results of student responses at the third and fourth meetings, it is known that student responses to the learning process tend to increase from previous meetings. This is indicated by the increasing number of students in the good and sufficient categories. This shows that student responses to changes in learning methods are very good. Given that students are familiar with the learning model with teaching materials that have been introduced twice before. So that the increase in student responses to the learning process will be better than before.

Self regulation is the opinion of students regarding the learning materials provided by the teacher. Self-regulation of these students describes attitude, motivation, alertness, concentration, time management, self-testing and finding learning resources. Student self-regulation of learning activities using distributed questionnaires is presented in Table 4 .

Table-4: Results of Observation of Students' Self-Regulation on Learning

\begin{tabular}{|l|c|c|c|c|c|c|c|c|}
\hline \multirow{2}{*}{ Student Response } & \multicolumn{2}{|c|}{$\mathbf{1}^{\text {st }}$ Meeting } & \multicolumn{2}{|c|}{$\mathbf{2}^{\text {nd }}$ Meeting } & \multicolumn{3}{c|}{$\mathbf{3}^{\text {rd }}$ Meeting } & $\mathbf{4}^{\text {th }}$ Meeting \\
\cline { 2 - 9 } & $\mathbf{N}$ & $\mathbf{\%}$ & $\mathbf{N}$ & $\mathbf{\%}$ & $\mathbf{N}$ & $\mathbf{\%}$ & $\mathbf{N}$ & $\mathbf{\%}$ \\
\hline Good & 6 & 21 & 9 & 32 & 10 & 36 & 16 & 57 \\
\hline Quite Good & 12 & 43 & 13 & 46 & 16 & 57 & 12 & 43 \\
\hline Not Good & 10 & 36 & 6 & 21 & 2 & 7 & 0 & 0 \\
\hline Total & 28 & 100 & 28 & 100 & 28 & 100 & 28 & 100 \\
\hline
\end{tabular}

Based on student self regulation at the first and second meetings, it was known that student selfregulation of the learning process tended to increase. This is indicated by the increase in the number of students in the sufficient category and the decrease in the number of students in the poor category. This shows that student self-regulation of changes in learning methods is very good. This is indicated by the attitude of students towards teaching materials studied properly and carefully so that they learn voluntarily.

Based on the results of student self regulation at the third and fourth meetings, it was known that students' self-regulation of the learning process also 
Fajar Kurnia et al., J Adv Educ Philos, August, 2020; 4(8): 351-360

tended to increase from the previous meeting. This is indicated by the increasing number of students in the good and sufficient categories. This shows that student responses to changes in learning methods are very good. This indicates that the learning tools delivered by the cooperative inquiry method and guided directing are able to increase student self-regulation.

\section{Instrument Effectiveness Test Results}

Assessment of the effectiveness of the use of teaching materials that have been applied to students, of course, is ultimately assessed based on indicators of cognitive learning outcomes, psychomotor learning outcomes, student affective learning outcomes and thinking skills as the output of the application of teaching materials and their models. Data analysis of the aspects of evaluating the effectiveness of the teaching materials is descriptively presented in the following explanation.

a. Cognitive learning outcomes

Table-5: Recapitulation of Learning Outcomes

\begin{tabular}{|l|c|c|c|c|c|c|c|c|}
\hline \multirow{2}{*}{$\begin{array}{l}\text { Cognitive learning } \\
\text { outcomes }\end{array}$} & \multicolumn{2}{|c|}{$\mathbf{1}^{\text {st }}$ Meeting } & \multicolumn{2}{c|}{$\mathbf{2}^{\text {nd }}$ Meeting } & \multicolumn{2}{|c|}{$\mathbf{3}^{\text {rd }}$ Meeting } & \multicolumn{2}{|c|}{$\mathbf{4}^{\text {th }}$ Meeting } \\
\cline { 2 - 9 } & $\mathbf{N}$ & $\mathbf{\%}$ & $\mathbf{N}$ & $\mathbf{\%}$ & $\mathbf{N}$ & $\mathbf{\%}$ & $\mathbf{N}$ & $\mathbf{\%}$ \\
\hline Mastery & 16 & 57 & 24 & 86 & 28 & 100 & 28 & 100 \\
\hline Not Mastery & 12 & 43 & 4 & 14 & 0 & 0 & 0 & 0 \\
\hline Total & 28 & 100 & 28 & 100 & 28 & 100 & 28 & 100 \\
\hline
\end{tabular}

Based on data related to student cognitive learning outcomes, it is known that the four meetings showed a tendency to increase. This is shown by the Minimum Mastery Criteria (KKM) value at the first meeting of only 57\%. Meanwhile, the second, third and fourth meetings showed a significant increase in the achievement of completeness. The increase in completeness is because the teacher has implemented the Guided Inquiry learning model based on the development of thinking skills. So that by applying this learning model will be able to increase student learning outcomes and the level of student understanding will also increase related to the material presented by the teacher.

b. Psychomotor Learning Outcomes

Students' psychomotor learning outcomes are assessed at each meeting. The student's psychomotor assessment was in the form of an observation sheet with an assessment based on an assessment rubric filled out by three observers. The results of students' psychomotor observations in the learning process of the first to fourth meetings are presented in Table 6.

Table-6: Psychomotor Learning Outcomes

\begin{tabular}{|c|c|c|c|}
\hline Psychomotor Learning Outcomes & Obs1 & Obs2 & Obs3 \\
\hline \multicolumn{4}{|l|}{$1^{\text {st }}$ Meeting } \\
\hline How to use the right pendulum & 2 & 2 & 2 \\
\hline Reads a lot of vibrations on the pendulum & 2 & 2 & 1 \\
\hline How to use the right Statif & 1 & 2 & 2 \\
\hline How to use the right Stopwatch & 2 & 1 & 2 \\
\hline total & 7 & 7 & 7 \\
\hline Category & Less Skilled & Less Skilled & Less Skilled \\
\hline \multicolumn{4}{|l|}{$2^{\text {nd }}$ Meeting } \\
\hline How to use Slinky & 3 & 3 & 4 \\
\hline How to Use the Meter & 3 & 3 & 4 \\
\hline How to use the right Stopwatch & 3 & 3 & 4 \\
\hline total & 9 & 9 & 12 \\
\hline Category & Sufficiently Skilled & Sufficiently Skilled & Very Skilled \\
\hline \multicolumn{4}{|l|}{$3^{\text {rd }}$ Meeting } \\
\hline How to use Slinky & 3 & 3 & 4 \\
\hline How to Use the Meter & 3 & 3 & 4 \\
\hline How to use the right Stopwatch & 3 & 3 & 4 \\
\hline total & 9 & 9 & 12 \\
\hline Category & Sufficiently Skilled & Sufficiently Skilled & Very Skilled \\
\hline \multicolumn{4}{|l|}{$4^{\text {th }}$ Meeting } \\
\hline Sequencing the experiment & 3 & 3 & 4 \\
\hline How to use a proper tuning fork & 3 & 3 & 4 \\
\hline Pay attention to the water level in the tube & 3 & 3 & 4 \\
\hline Total & 9 & 9 & 12 \\
\hline Category & Sufficiently Skilled & Sufficiently Skilled & Very Skilled \\
\hline
\end{tabular}


Fajar Kurnia et al., J Adv Educ Philos, August, 2020; 4(8): 351-360

Based on the results of students' psychomotor learning at the first meeting, it was known that the three observers stated that students were still less skilled in psychomotor aspects. This is because the teacher is still unable to apply the Guided Inquiry learning model. Furthermore, after knowing the students psychomotor abilities, the teacher applied the Guided Inquiry learning model and the result was that the students abilities, especially the psychomotor aspects, had increased from the second meeting to the very skilled fourth meeting. In line with Sukariasih, et al. [15] which states that inquiry skills in groups of students obtain average scores satisfactorily. Likewise with Hutabarat, et al. [16] which states that there is an increase in the development of student activity in the experimental class during learning using the guided inquiry learning model. These results suggest that applying the Guided Inquiry model can improve students 'psychomotor learning outcomes, especially students' understanding of the use of materials used for practicum (experiment).

\section{c. Affective learning outcomes}

Student affective learning outcomes are assessed at each meeting. The student affective assessment is in the form of an observation sheet with an assessment based on an assessment rubric filled out by three observers. The results of student affective observations in the learning process of the first to fourth meetings can be presented in Table 7 .

Table -7: Affective learning outcomes

\begin{tabular}{|l|c|c|c|}
\hline \multicolumn{1}{|c|}{ Affective Aspects } & Obs1 (\%) & Obs2 (\%) & Mean (\%) \\
\hline Curiosity & 59 & 66 & 65 \\
\hline Be thorough & 73 & 72 & 74 \\
\hline Responsible & 74 & 71 & 75 \\
\hline Cooperate & 74 & 74 & 76 \\
\hline Contribute ideas / opinions & 81 & 77 & 81 \\
\hline A good listener & 77 & 81 & 82 \\
\hline Average & $\mathbf{7 3}$ & $\mathbf{7 4}$ & $\mathbf{7 5}$ \\
\hline Category & Mastery & Mastery & Mastery \\
\hline
\end{tabular}

Based on data related to student affective learning outcomes, it is known that from 4 meetings it shows a tendency to increase. This is shown by the KKM value at the first meeting of only $73 \%$. Meanwhile, the second, third and fourth meetings showed an increase in completeness achievement. In line with Pardede, et al. [17] which stated that the learning outcomes taught by the inquiry training (IT) learning model in the low motivation group obtained an average of 10.25 and in the high motivation group (MT) with the inquiry training (IT) learning model obtained an average of 12.16. The increase in completeness is because the teacher has implemented the iquiri learning model, which is in the form of cooperative learning based on the development of science process skills and with scientific development. So that by applying this learning model will be able to increase student learning outcomes and the level of student understanding will also increase related to the material presented by the teacher.

Based on this affective aspect, students also showed an increase in the attitudes shown towards the learning process. This is shown by students often expressing their ideas during the interaction process with teachers and with friends in groups. In addition, students on average become good listeners when the teacher explains and explains the material presented. So that with this attitude will be able to improve student affective learning outcomes.

\section{RESEARCH DISCUSSION}

\section{Validity Learning Tools}

The validation of learning tools in this study was carried out by three interested parties, namely by experts, practitioners and students. The results of the validation test of learning tools by the three parties all of them stated that they were quite valid by making a few improvements. Teaching materials that are validated by experts and practitioners are vibration, wave and sound teaching materials which are developed consisting of a cover, foreword, table of contents, concept map, competency standards, basic competences, learning objectives, chapter titles along with the contents of vibration and wave material, summary, competency test, glossary, and bibliography. In the content of vibration, wave and sound material containing subject matter, there are let's think (questions that can train students' thinking skills), sample questions and discussion (practice reasoning), short practicum procedures (let's try), application of subject matter (in life), and get to know scientists. The general assessment by the validator stated that the teaching material was good and could be used with a few revisions.

While the results of validation by students were related to the readability of teaching materials and the readability of students' worksheets. The results of validation by students stated that the teaching materials and worksheets of students were declared valid enough but needed a little improvement. This improvement is the need to improve the language used and more understandable to students. So that students more easily 
Fajar Kurnia et al., J Adv Educ Philos, August, 2020; 4(8): 351-360

understand the meaning and meaning of the material presented by the teacher.

\section{Practical Learning Tools}

The practicality of the learning tools applied in the learning process is first measured based on the implementation of the lesson plan (RPP). The stages in the RPP describe the systematic delivery of material that must be taken at each meeting. It will be easier for the teaching staff if the practical level of the lesson plan is relatively easy and understandable. In addition to the feasibility of the lesson plan indicators in research related to the practicality of learning devices, it was also measured based on teacher activity, student activity and self-regulation.

Based on the results of observations and students' responses regarding teaching materials made as teaching materials, it can be stated that the teaching materials are practical enough to be applied. The practicality of the teaching materials is marked by the fulfillment of the implementation of learning with good teacher activity, the response of students to the teaching materials which is quite good and the students' selfregulation that is quite good as well.

Based on the aspect of teacher activity in accordance with the results of the observer's assessment, it is known that during the four teacher activity meetings there tends to be an increase. It's just that at the first meeting the teacher still made adjustments to the currently applied model, so that at the first meeting the teacher's activities tended to look less good. Meanwhile, after the teacher understands and understands the meaning of the teaching material, the activity tends to increase. This is marked by the second to fourth meetings in the good category. This increase was shown by the teacher with his ability to carry out core activities, namely starting from the activity of explaining the interpretation of the material being taught, giving direction and explaining how to analyze the problems faced and being able to carry out his role to deliver discussion direction. The role of core activities which is quite important is that teachers are able to direct students to be able to explain and conclude the learning outcomes they have learned, in line with the research of Ryan, et al. [18] where the teacher-to-student approach using the Inquiry model is increasingly limited.

Based on the response aspect of students according to the answers, it is known that during fourth meetings the students' responses tend to increase. The response of these students is indicated by a significant increase in the attitude they show. This attitude, among others, at the first meeting showed a bad attitude, while at the second to fourth meetings showed a good attitude towards the teaching materials provided. This fairly good attitude was shown by students with an attitude that began to be interested and like the teaching materials using the learning model applied by the teacher.

Based on the aspect of self-regulation of students in accordance with the answers, it was known that during the fourth meeting the students' responses tended to increase. The increase in the self-regulation aspects of these students was indicated by good attitudes and motivation. In addition, awareness of time management and adding learning resources has also increased. Another visible self-regulation of students is a change in the way they solve the problems they face, which is shown more carefully in making answers and concentrating more on understanding the learning problems at hand.

Based on the results of observations related to the practicality indicator of the learning device, it shows that the practicality of the lesson plan and indicators of teacher activity, student activity and self-regulation looks quite good. Teacher activity tends to increase from one meeting to the next. This can also be seen in the activity aspect of students who also experienced an increase, from which initially less active students became more active from each meeting. Regarding the device that has applied student self-regulation also experienced an increase, most students stated that all aspects of self-regulation were quite good.

The results of this study are in line with the research conducted by Safitri, et al. [19] which states that the practicality of the learning device is categorized as very good from the level of suitability of the stages of learning implementation using the guided inquiry learning model. RPP implementation observation sheet.

\section{Effectiveness Learning Tools}

Based on the results of testing the teaching materials carried out by observers and teachers in the field of study, the effectiveness of learning devices can be declared effective. The effectiveness of these teaching materials is marked by the achievement of aspects of learning outcomes cognitive, psychomotor, and affective of students. In line with Kusuma, et al. [20] which states that guided inquiry learning models and scientific performance have an effect on learning outcomes.

This is indicated by the indicator of the effectiveness of the cognitive assessment sheet learning tool showing a tendency to increase student achievement. The increase in learning achievement is marked by the achievement of KKM that exceeds the stipulated (70). The increase in student learning outcomes is of course due to a change in the learning model carried out conventionally to the Guided Inquiry learning model. In line with the research of Rahayu et al. [21] where the learning outcomes of students by learning using the guided inquiry model are higher than the general model of learning used in schools. In this 
Fajar Kurnia et al., J Adv Educ Philos, August, 2020; 4(8): 351-360

case the teacher acts as a direct instruction and also as a guide when there is a dispute which may require clarification of the truth of the scientific answer. In line with Mulyana, et al. [1] Guided inquiry learning models and scientific performance have an effect on learning outcomes. In line with Lohner, et al. [22] which states that there is an increase in the average student learning outcomes from $39.05 \%$ to $76.7 \%$.

The next indicator is the achievement of the aspects of students' psychomotor learning outcomes that have been achieved, namely during the first meeting to the fourth meeting that shows a significant increase. This increase is indicated by the increase in students' skills in using and utilizing the materials used in the learning process. The students' understanding is shown by their understanding of the use of pendulum, slinky, thermometer and meter. And then they are able to carry out and assemble the experiments suggested by the teacher properly.

The next indicator is the achievement of the affective aspects of the learners' learning outcomes has been achieved, that is, at the end of the meeting the affective aspect reaches the sufficient and good category. Meanwhile, students who are in the poor category are no longer there. The increase in the affective aspect with the increase in character skills of students is indicated by the curiosity of students towards the material presented by the teacher. In addition, students are also more careful in solving problems faced in the learning process. Affective aspects related to social skills have also increased. These social skills are shown by students by answering questions responsibly, in this case using scientific answers and in accordance with the material that has been taught. In addition, cooperation, awareness of contributing ideas (ideas) and enthusiasm in following the learning process were also shown well by students. So that teachers can be helped by changes in the attitudes shown by these students. Based on the results of research, the affective aspects of students have increased, namely reaching the category of being quite active from those previously less active.

The next indicator is the achievement of the learning outcomes of the thinking skills of students, namely at the last meeting the ability of students on average showed a critical attitude. The increase in this aspect of thinking is due to a change in the learning model, from the previous one with the conventional method to the Guided Inquiry learning model. The skills of these students can be seen in the ability of students to interpret the learning problems faced and then analyze according to scientific provisions, so that the truth will be reached. These skills are also shown by students being able to understand questions logically (inference) and also able to explain the material being asked by the teacher when asked to explain the problems faced in the learning process.
Based on the results of research that has implemented the learning tools designed by the researcher, it shows that the level of effectiveness is quite good. The effectiveness of these devices is based on the achievement of cognitive, affective, psychomotor learning outcomes and the skills of students who have a tendency to experience improvement at each meeting. The successful application of these learning tools is certainly balanced with the use of appropriate learning models, namely in this study the Guided Inquiry approach.

This is in accordance with the opinion of Eggen [23] which states that one of the effective learning models for developing students' thinking skills is guided inquiry or what is often referred to as guided inquiry. The guided inquiry model is a teaching model designed to give students experience of the scientific method. The advantage of the inquiry model according to Eggen [23] is that it is designed to help students gain an in-depth understanding of the scientific method while developing their critical thinking, self-regulation, and understanding of specific topics.

The results of this study are in line with research conducted by Kasmurie, et al. [24] proving that Guided Inquiry learning can improve students' thinking skills, so it needs to be emphasized in each school as an alternative learning method. in school. This is in line with the results of Purwanto [25] that the level of Guided Inquiry learning model can train students 'intellectual ability which is in line with the indicators of students' thinking skills. Inquiry-based learning integrated with modules provides significant results in improving students' thinking skills. The results of research from Kumari, et al. [26] also show that guided inquiry-based learning integrated with modules makes student learning experiences much more meaningful and more actively involved in teaching and learning activities.

Learning tools using the Guided Inquiry model are devices designed to contain problems that occur in the environment that require proof of the experimental process through scientific methodologies that stimulate students to find concepts independently so as to produce meaningful discoveries. This is relevant to Ausubel's learning theory that tries to find solutions to problems and the knowledge that accompanies them will result in truly meaningful knowledge [27]. In line with Buffington [28] statement those students' thinking skills can develop if the teacher periodically involves thinking skills in stages. The same thing is attempted in guided inquiry based learning tools, in the syllabus, lesson plans, student worksheets, and the assessment sheet which contain periodic learning activities containing student skills to observe, interpret data, analyze, and explain. 
Fajar Kurnia et al., J Adv Educ Philos, August, 2020; 4(8): 351-360

\section{CONCLUSION}

1. Syllabus, material analysis, lesson plans, worksheets and other learning tools have a good average validity, with a few revisions. The validation of the tools was carried out by two experts and one practitioner. The readability test of teaching materials and assessment worksheets by students, the devices developed were quite valid with a few revisions. This is reinforced by the responses of students who state that the learning prototype applied can be easily understood.

2. The lesson plans produced have practical value, namely by achieving the learning stages properly. This is reinforced by the results of observations, it can be stated that teacher activity, student activity, and student selfregulation have increased from one meeting to the next.

3. The effectiveness of developmental learning tools is based on increasing cognitive learning outcomes, affective learning outcomes, psychomotor learning outcomes, and thinking skills from one meeting to the next.

\section{REFERENCES}

1. Mulyasa, E. (2013). Pengembangan dan implementasi kurikulum 2013. PT Remaja Rosdakarya.

2. Kemendikbud, Litbang. (2011). Survei Internasional TIMSS. Access on http://litbang_Kemendikbud.go.id/Index.php.Surve i.InternasionalTIMSShtml on February 19, 2014.

3. OECD. (2016). PISA 2015 Results in Focus. New York: Columbia University.

4. Firman, H. (2014). Penelitian Pendidikan: Jenis, Teknis, dan Instrumentasi. Prosiding Seminar Nasional Pendidikan IPA, Jurusan Pendidikan IPA FITK UIN Syarif Hidayatullah, Jakarta, September 11.

5. Amri, S., \& Ahmadi, I. K. (2012). Proses Pembelajaran Kreatif dan Inovatif dalam Kelas. Jakarta: Prestasi Pustakaraya.

6. Ambarasari, R. Y. (2014). Pengaruh Model Problem Based Learning dan Cooperative Learning Tipe Think Pair Share Terhadap Prestasi Belajar IPA Ditinjau dari Minat Siswa Kelas V SD Kecamatan Bulukerto Tahun Pelajaran 2012/2013. Jurnal Ilmiah Mitra Swara Ganesha, 1(1).

7. Hartono, R. (2013). Ragam Model Mengajar yang Mudah diterima Murid. Yogjakarta: Diva Press.

8. McBride, J.W., Bhatti, M.I., Hannan, M.A \& Feinberg, M. (2012). Using An Inquiry Approach To Teach Science To Secondary School Science Teachers. Procedia - Social And Bahavioral Sciences 46, 2327-2333.

9. Schaal, S., Matt, M., \& Grübmeyer, S. (2012). Mobile Learning and biodiversity-bridging the gap between outdoor and inquiry learning in pre- service science teacher education. Procedia-Social and Behavioral Sciences, 46, 2327-2333.

10. Kong, S. C., \& So, W. M. W. (2008). A study of building a resource-based learning environment with the inquiry learning approach: Knowledge of family trees. Computers \& Education, 50(1), 3760.

11. Yenny, M. (2014). Pengaruh Pendekatan Inkuiri Terbimbing Terhadap Peningkatan Kemampuan Pemecahan Masalah Matematis Siswa SMP. Jurnal Pendidikan dan Keguruan, 1(2).

12. Balitbang, K. (2014). Laporan Hasil Ujian Nasional 2014. Jakarta: PusatPenelitian Pendidikan.

13. Nasir, M., Fakhrunnisa, R., \& Nastiti, L. R. (2019). The implementation of project-based learning and guided inquiry to improve science process skills and student cognitive learning outcomes. International Journal of Environmental and Science Education, 14(5), 229-238.

14. Tessmer. (1998). Planning and Conducting Formative Evaluations. Philadelphia: Kogan Page.

15. Sukariasih, L., Saputra, I. G. P. E., Ikhsan, F. A., Sejati, A. E., \& Nisa, K. (2019). Improving the learning outcomes of knowledge and inquiry skill domain on third grade students of smp negeri 14 kendari through the guided inquiry learning model assisted by science kit. Geosfera Indonesia, 4(2), 175-187.

16. Hutabarat, F. I., \& Juliani, R. The Effect of Learning Inquiry Training Model on Student Learning Outcomes on Measurement Materials. Jurnal Pendidikan Fisika, 6(1), 13-19.

17. Pardede, Dahlia, M, Manurung, S.R. (2016). Pengaruh Model Pembelajaran Inquiry Training Dan Motivasi Terhadap Hasil Belajar Fisika Siswa. Jurnal Pendidikan Fisika p-ISSN 2252-732X eISSN 2301-7651.

18. Ryan, T. G., \& St-Laurent, M. (2016). Inquirybased learning: observations and outcomes. Journal of Elementary Education, 26(1), $1-22$.

19. Safitri, R., Jamal, M. A., \& Salam, A. (2015). Pengembangan Perangkat Pembelajaran IPA SMP Berorientasi Keterampilan Berpikir Kritis pada Pokok Bahasan Getaran dan Gelombang dengan Model Pembelajaran Inkuiri Terbimbing. Berkala Ilmiah Pendidikan Fisika, 3(3), 170-175.

20. Kusuma, R. (2019). Guided Inquiry Model Effect on Student Learning Outcomes. International Journal of Physic Education Department, 1166, 16.

21. Rahayu, A. B., Hadi, S., Istyadji, M., Zaini, M., Sholahuddin, A., \& Fahmi, F. (2018). Development of Guided Inquiry Based Learning Devices to Improve Student Learning Outcomes in Science Materials in Middle School. European Journal of Alternative Education Studies.

22. Löhner, S., van Joolingen, W. R., Savelsbergh, E. R., \& van Hout-Wolters, B. (2005). Students' 
reasoning during modeling in an inquiry learning environment. Computers in Human Behavior, 21(3), 441-461.

23. Löhner, S., van Joolingen, W. R., Savelsbergh, E. R., \& van Hout-Wolters, B. (2005). Students' reasoning during modeling in an inquiry learning environment. Computers in Human Behavior, 21(3), 441-461.

24. Kitot, A. K. A., Ahmad, A. R., \& Seman, A. A. (2010). The effectiveness of inquiry teaching in enhancing students' critical thinking. ProcediaSocial and Behavioral Sciences, 7, 264-273.

25. Purwanto, W. L., \& Hidayat, R. (2013). Analisis Kemampuan Inkuiri dan Hasil Belajar Siswa
Sekolah Menengah Pertama melalui Model Pembelajaran berbasis Model Hierarki Of Inquiry. Prosiding Pertemuan Ilmiah XXVII HFI Jateng \& DIY, Solo, 23, 0853-0823.

26. Kumari, K., \& Kulshrestha, A. K. (2013). Impact of contstructivist inquiry-based learning approach on science achievement at grade VIII. International Journal of Aplied and Studies, 2, 1-5.

27. Dahar, R. W. (2011). Teori-teori belajar dan pembelajaran. Jakarta: Erlangga.

28. Buffington, M. L. (2007). Contemporary approaches to critical thinking and the wold wide web. Art Education, 60(1), 18-23. 